\title{
Qualitative Analysis on the Factors Affecting Exclusive Breastfeeding among Working Mothers at Community Health Center in Bangkalan, Madura
}

\author{
Dwi Wahyuning Tiyas'), Bhisma Murti',2), Dono Indarto²) \\ ${ }^{1)}$ Masters Program in Public Health, Universitas Sebelas Maret \\ ${ }^{2)}$ Faculty of Medicine, Universitas Sebelas Maret
}

\begin{abstract}
Background: Exclusive breast milk is the main food for infants aged o- 6 months. Breast feeding can be extended up to 2 years with complementary food. The prevalence of exclusive breast feeding is targeted to exceed $80 \%$. A study has shown some factors may determine exclusive breastfeeding among working mothers, such as desire to return to work soon after giving birth, distance from home to the workplace, and supporting facilities (e.g. Space, freezer) at the workplace. This study aimed to investigate factors affecting exclusive breast feeding among working mother at the workplace.

Subjects and Method: This was a qualitative study with phenomenology approach. This study was conducted at the Community Health Center, Bangkalan, Madura. A total of 9 working mothers were purposively selected as informants. The administrators at the workplace were interviewed as another source of information. Some family members were also selected as informants. The data were collected by interview, observation, taking photos, and document review (e.g. Maternal and child health book).

Results: Exclusive breastfeeding was associated with workplace support for breastfeeding. Adequacy of breastfeeding facility at the workplace was described by mothers as having a place allocated for expressing breast milk and provision of flexible time to express breast milk other than the usual rest time. Most of mothers who were interviewed breastfed their babies for less than three months. Mothers who worked in workplaces that did not provide breastfeeding rooms and refrigerators were more likely to discontinue breastfeeding. Lack of flexible time to express breast milk was also associated with breastfeeding discontinuation. The existence of policies breastfeeding leave, arrangement for light duty after delivery, and flexible working hours, were associated with breastfeeding.

Conclusion: Provision of adequate breastfeeding facilities at the workplace, such as a room in which to express breast milk, and a refrigerator, as well as the existence of policy that allows mothers to have flexible time to express breast milk, are important determinants for exclusive breast feeding among employed mothers.
\end{abstract}

Keywords: exclusive breast feeding, working mothers, workplace

\section{Correspondence:}

Dwi Wahyuning Tiyas. Masters Program in Public Health, Universitas Sebelas Maret, Jl. Ir. Sutami 36A, Surakarta, Central Java, 57126.

\section{BACKGROUND}

Breast milk is the main food for infants. WHO recommends (2011) the optimal way of delivering food to infants through exclusive breastfeeding for up to 6 months, then the baby can be fed complementary feeding, and breastfeeding continues until the child reaches the age of 2 . The duration of breastfeeding in mothers in developing countries is shorter than mothers in low-income countries (Victora et al., 2016). In line with the study in Nigerian society only $19 \%$ of mothers are able to exclusively breastfeed (Agunbiade and Ogunleyes, 2012). Indo- 
nesia as a developing country, the achievement of exclusive breastfeeding in 2013 only reached $54.3 \%$. East Java Provincial Health Office reports on exclusive breastfeeding only reached $47.88 \%$ (Ministry of Health RI, 2014), while exclusive breastfeeding data in Bangkalan District in 2015 was $69.3 \%$. Based on the nutrition report of Bangkalan Health Center in February 2016, exclusive breastfeeding in infants o-6 months from 655 babies examined, only 75 babies who were given exclusive breastfeeding. The data are still below the MDG's 2015 target of $80 \%$.

Based on preliminary studies on working mothers with infants aged 0-12 months in Bangkalan Health Center work areas, aspects of family roles, local customs, health workers, ignorance in breastfeeding, working motherhood conditions, endless maternity leave, inadequate rest period, lack of facilities that support the mother in breastfeeding the baby, the distance to the workplace, become the reason for the mother not to give exclusive breastfeeding to her baby. Barriers in exclusive breastfeeding or early termination of breastfeeding less than 6 months are often associated with working motherhood and the increasing number of female labor force (IDAI, 2010). The 2013 BPS survey, of 114 million people (94\%) of workers, $38 \%$ of whom are female workers (43.3 million) and 25 million of whom are in reproductive age (BPS, 2013). Women's participation in the increase in the labor force in February 2014 reached $53.4 \%$ of the 125.3 million labor force (ILO, 2015). Guendelman et al. (2009) states that the probability of exclusive breastfeeding success is increased in women who do not return to work after childbirth.

The Government of Indonesia makes regulations to support breastfeeding in the workplace, such as Government Regula- tions on exclusive breastfeeding and the Regulation of the Minister of Health on procedures for the provision of special facilities for breastfeeding and/or milking. Implementation of the regulation is expected to increase the achievement of exclusive breastfeeding on a national scale, on the other hand improving health, increasing the productivity of women's work, and fulfilling children's rights on exclusive breastfeeding. This study is a qualitative analysis to determine the length of maternity leave, how to breastfeed, and the availability of lactation room facilities with exclusive breastfeeding to the working mother in Bangkalan Health Center area.

\section{SUBJECTS DAN METHOD \\ 1. Study Design}

This study was an qualitative study with phenomenology approach to explore the view of mothers who work on exclusive breastfeeding, experience of exclusive breastfeeding success, duration of maternity leave received, and availability of lactation room facilities to achieve exclusive breastfeeding success. In this phenomenological study, to understand the meaning of an event and its relation to people who are in certain situations (Moleong, 2010). The study was conducted in the working area of Community Health Center, Bangkalan, Madura, in July 2016.

\section{Population and Sampling}

The data were obtained from 9 working mothers with 6 month old children as informants. The selection of informants used purposive sampling technique where the informants ware chosen carefully using certain criteria so as to provide rich and detailed data on the research problem (Murti, 2013) that was successful working mother and unsuccessful giving exclusive breastfeeding. 


\section{Study Instruments}

The data were collected by a semistructured interview, photo observation, and document review (maternal and child health book). The validity of the data is achieved using triangulation of data or sources by comparing the observed data with interviews, documents with interview results, and also comparing what people say in public with what they said personally (Patton, 1983), done by collecting information from mother's family member, and the institution where the mother works.

\section{$\frac{\text { RESULTS }}{\text { 1. Characteristics of informant study }}$} Informants age varied between 26-35 years, from high school to graduate level. Mothers worked in government agencies and private agencies. The majority of informants were 7 Madurese and 2 Javanese. The birth status of 4 people were the third child, 4 people were the first children and 1 person was the fourth child. Majority of informants gave birth to Sectio Caesaria (SC) as many as 6 people, and 3 informants gave birth in pervaginam (spontaneous).

\section{Informants view of exclusive breastfeeding}

Based on interviews with 9 informants, 5 informants expressed the opinion that exclusive breastfeeding is important to the infant. Two informants said breastfeeding is a form of mother's obligation to her baby, to be a personal mandate, and a child's right. Informants felt the benefits of breastfeeding perceived by the mothers and the babies were good for the health and strength of the babies' body, the babies never had a cold and cough. The informants said their babies were more susceptible to cough and cold. Breastfeeding improves the baby's weight. Babies did not have digestive disorders such as constipation and diarrhea, not experiencing inflammatory reactions in the form of heat and fussy when teething, good for health, baby quickly recovers from hot pain. By breastfeeding, a mother would be closer to the baby, inexpensive, easier during the night because no need to make other food, more efficient because there is no need to buy bottles and milk, more comfortable to the body and cost. Two informants said they lost weight or became thinner, giving a feeling of pride and satisfaction to be a mother and, mothers felt more comfortable when they could breastfeed.

All informants knew that exclusive breastfeeding was only breastfeeding for 6 months, without other complementary foods, without canned milk, without food mixing, without any additional supplement. Information on exclusive breastfeeding could be obtained through the internet, sharing of exclusive breastfeeding experiences with other friends, neighbors or social modeling of working mothers, and relatives who succeeded in giving exclusive breastfeeding, reading study results, mass media, television, newspapers, attending seminars.

\section{Successful experience of working mothers in giving exclusive breast- feeding}

Two informants managed to give breast milk alone as the main food for her baby for 6 months. Informants said that they had given formula milk besides breast milk, at the beginning of the baby's birth. The formula milk feeding could be stopped entirely when the informants felt the breast milk was produced to be given. Informants said that she gave formula milk once, when the condition of the mother was sick. Informants who gave formula milk in the early birth of the baby explained the reason for giving formula milk was because the breast milk was not coming yet, not smooth, yet the mother and family thought 
that the babies cranky and cried because of hunger.

Successful informants gave exclusive breastfeeding and dominant breastfeeding, received support from friends and family (parents, husbands.). Forms of support that was, the husband never suggested to use formula milk, reminded the mother to consume food that met her needs, help taking care of the baby when the mother pumped milk, husband met the needs of nutrition intake in the form of milk, fresh fruit or fruit juice, breastmilk supplements, reminded the time to go home to breastfeed, to clean the dairy store. Mothers had a loose working time, workplace institutions provided an opportunity to exclusively breastfeed for 6 months by not doing outside work and just staying in the office, recommended exclusive breastfeeding, close working distance, and recognizing the success of exclusive breastfeeding in the previous children.

In order to obtain a large amount of breast milk, the mother performed exciting activities, relaxed and rested adequately, ate nutritious foods (eg, milk for breastfeeding mothers, breastfeeding vitamin supplements, fruit or fruit juices, green bean juice, and herbs), used comfortable and painless breastfeeding pumps, and avoided fatigue and stress during breastfeeding.

The duration of exclusive breastfeeding, there were 2 informants only gave breast milk exclusively for 1 week, 1 informant gave breast milk exclusively for 2 months, and 1 informant had given formula milk since the beginning of the baby's birth. The reason the informant gave the formula milk as a substitute for breast milk, were because of her maternity leave has finished, milk production was pumped into small amounts, fussy children, and sick children.

\section{Effect of maternity leave duration on exclusive breastfeeding}

The duration of maternity leave received by informants were varied, such as 3 informants gave birth to first child got maternity leave for 3 months and 1 informant got maternity leave for two months. Maternity leave received for the third child, were 1 informant for 3 months, 2 informants for 2 months and 2 informants got long maternity leave for 40 days.

During the maternity leave, the informants said the benefits of giving maternity leave. They were feeling closer to the baby, the informants had time to care for and babysitting the baby, the mother knew better the child's development. Mothers could use the time off work to adapt, the mother's mind was not consumed by office work, the mother felt more comfortable, relaxed and calm. The time of maternity leave was used by informants to teach the baby drink breast milk by bottle.

The informants who gave milk said they were more frequent in breastfeeding, had more time, comfortable, more relaxed and not being chased by time or rush, more focused to breastfeed, could directly breastfeed, anytime could be given breast milk, half an hour, an hour and not until two hours the mother could breastfeed the baby. When the time of maternity leave came to an end, the mother said that the breastfeeding process was rushed, the breast was swollen, and the baby was not woken up for breastfeeding when the baby was entrusted to the baby's nursery.

\section{Availability of lactation room at work}

There is one institution where the informant work had lactation room, which was fulfill the standard, but the mother was not present during socialization, there was no signage in the "lactation room", the information delivery done by the head of 
institution during socialization, working mothers did not understand the function of lactation room, so that there was a difference of information received. Institutions where the informant worked that had not been specifically provided nursing areas, said there had been no working mothers who deliver to institutional needs nursing areas, and on average mothers pumped breast milk at home.

The informants said that the existence of lactation room with other supporting facilities was needed for the working mother who wanted to pump breast milk, the working mother who could not go home every two hours to breastfeed her baby and for the working mother who gave exclusive breast feeding to the baby, as well as working mother whose work environment had male employee.

\section{DISCUSSION}

For a mother, breast feeding to her baby becomes an inherent task for women. A woman is physically created to have a breast in which one of the organ functions is producing milk. The benefits perceived by informants during breastfeeding made informants believe that breastfeeding was available only when mothers breastfeed their babies became a necessary necessity for their babies, so there were informants who had the view that breastfeeding and feeding for an infant was important, and should be given.

Benefits of exclusive breastfeeding for infants were the baby never had a cold, cough, did not have digestive disorders such as difficult bowel and diarrhea, did not experience inflammatory reactions in the form of heat and fussy teething, good for endurance, and could increase body weight baby. Other benefits of breastfeeding were also felt by the mother. Mothers felt closer to the baby, not expensive, easier at night because it did not need to make formula milk, and the mother's weight got down. Breastfeeding was more efficient because there was no need to buy bottles and milk. The results of this study reinforce the existing theory of the benefits of breastfeeding. According Roesli (2013), Smith (2009) and Cohen et al. (1995) exclusive breastfeeding can lead to a bond of love between mother and child. Breast milk is the best food/ nutrition for baby, the price is not expensive, improving health and intelligence, increase endurance, can reduce the mother's weight, save time, give satisfaction for mother, protection of infants against disease.

High education influenced informants to obtain information about exclusive breastfeeding from various sources, such as internet media, television, newspapers, magazines, or experience sharing among friends, neighbors, roles, family, siblings who successfully deliver exclusive breastfeeding. Informants' exposure to information about the success of exclusive breastfeeding can provide a positive response to knowledge related to the informant's educational background (Ludvigsson, 2003).

Informants age range 26-35 years old was productive age. Successful experience in exclusive breastfeeding at previous births, the perceived benefits of exclusive breastfeeding, family support for maternal decisions on breastfeeding, high level of education, good understanding of exclusive breastfeeding, positively responded to informants actions in exclusive breastfeeding. According to Giri and Ayubi (2012), women in age range 20-30 years have multiple roles. As she gets older, she will become increasingly exposed to information, thus increasing her knowledge.

The condition of the mother who was sick, the view of the mother who assumed breastfeeding had not come out, not smoot- 
hly in the early days of the baby's birth, and the need of a baby would affect the mother's mother so the mother thought that the baby was fussy, supported by the reaction of others in the family, parents and husbands, also influenced the mother's emotions, so the mother decided to give food or drink, other than breast milk to meet the needs of the baby. Formula feeding was given as a substitute for breast milk due to the reasons as the mother pursued breastfeeding debt after they leave, breast milk could not be squeezed, low supply of breast milk, breast milk did not come out, children fussy, the condition of a sick baby.

The condition of the mother, the reaction of the baby and the person around the mother in this case family members, the work environment can affect the emotions and attitudes of the mother in making decisions. According to Azwar (2003) the formation of attitudes is also influenced by personal experience, culture, other important people, mass media, institutions or institutions and emotional factors in the individual concerned.

Working leave for a certain period of time in women who experience labor was given at the time of her first, second, third child's childbirth. Maternity leave for working mothers who would give birth to the fourth child and so on to female civil servants was 1 month before and 2 months after childbirth. The length of time for maternity leave might vary for each individual woman and depending on the conditions and complications that the mother receives. The length of maternity leave might also depend on the work hazard in the workplace environment.

It is stated in Law No. 13 (2003) that female workers/laborers are entitled to rest 1.5 months before childbirth and 1.5 months after delivery according to the obstetrician's and/or midwife's calculations, or for at least 3 months with the right to obtain their full wages and Government Regulation No 24 of 1976 that the duration of maternity leave given is 1 (one) month before and 2 (two) months after childbirth. Maternity leave and childbirth become the rights of working women to be given by government agencies and private institutions in which there are female workers.

The time of maternity leave was used by informants to take care of the baby. Adaptation of the baby to the new environment, time management, preparing to prepare the family environment, physically unempowered mother, and mother mind not occupied by office work, informants could be more comfortable, relaxed and calm to teach breastfeeding her baby using a bottle. Informants could often provide breast milk to their babies, mothers felt of not being chased by time for breastfeeding, mothers became more focus on breastfeeding, mothers could breastfeed her baby directly at anytime. When the time of maternity leave came to an end, the informants who gave breast milk revealed a picture of a change in breastfeeding or breastfeeding time. BWI (2015) stated that the provision of maternity childbirth leave for a woman is undertaken in order to protect health, in this case to meet the physical and psychological needs of a mother and her child.

In the workplace there was not specifically a lactation room for the working mother to breastfeed and pump breast milk. However, there was an empty space/ unused space, that could be utilized by the working mother. Lactation room facilities (refrigerator) were not available specifically. The existence of lactation room was necessary for working mothers who wished to pump breast milk, because they were not allowed to go home every two hours to 
breastfeed their babies, as well as there were male employees in the work environment.

In accordance with Regulation of the Minister of Health No 15 of 2013 that the provision of lactation room facilities and infrastructure must be in accordance with minimum standards and needs. The informant felt more comfortable when pumping and breastfeeding at home, because the workplace was not too far away, the storage of breast milk at home was sufficient when the mother came out to work, troublesome and complicated to pump in the workplace, working time was not too long, felt being chased by time or rush in the workplace, time limit, no time due to office activities, and it was still taboo in the workplace environment.

The results of this study indicated that the perceived benefits of breastfeeding for infants, understanding of exclusive breastfeeding, maternal education level, information exposure, environmental support, no lactation room could respond to the actions of working mothers in exclusive breastfeeding. This response was reflected at the time of breastfeeding when the mother returned to work.

\section{REFERENCE}

Abdullah AF (2002). Menjadi Ibu Dambaan Umat. Jakarta: Gema insani press

Agunbiade MO, Ogunleyes VO (2012). Constraints To Exclusive Breastfeeding Practice Among breastfeeding Mothers In Southwest Nigeria: Implications For Scalling Up. Journal International Breastfeeding 7:5.

Alhamda S (2015). Buku Ajar Sosiologi Kesehatan. Yogyakarta: Depublish

Ariani (2012). Ibu, susui aku!. Bandung; Khasanah Intelektual.

Arora S, Cheryl M, Khun P, Wehrer J (2000). Major Factors Influencing
Breastfeeding Rates: Mothers Perception Of Fathers Attitude and Milk Supply. The American Academy of Pediatrics, 106 (5).

Australian Institute of Health and Welfare (2011). Australian National Infant Feeding Survey: Indicatorresults. Canberra: AIHW.

Ayah bunda (2016). Alasan Ibu Bekerja Pasca Punya Anak. www.Ayah bunda.co.id/keluarga-sikologi/alasan-ibubekerja-paska-punya-anak diakses 17 maret 2016.

Azwar S (2012). Sikap Manusia, Teori Dan Pengukurannya. Yogyakarta: Pustaka Belajar.

Baker M, Milligan K (2008). Maternal employment, breastfeeding, and health: Evidence from maternity leave mandates. Journal of Health Economics 27: 871-887.

Better Work Indonesia (BWI) (2015). Panduan Untuk Pengusaha Tentang Perlindungan Ibu Hamil di Tempat Kerja. www.Betterwork.org/indonesia. Diakses 27 januari 2016.

BPS (2002). Klasifikasi Baku Jenis Pekerjaan Indonesia (KBJI). Jakarta: Sub Direktorat Klasifikasi dan Pembakuan Statistik, Direktorat Metodologi Statistik.

Cadwell K, Turner M (2011). Buku Saku Manajemen Laktasi. Jakarta: EGC.

Cohen R, Mrtek MB, Mrtek RG (1995). Comparation Of Maternal Absente eism and Infant Illness Rates Among Beastfeedin and Formula Feeding Oman In Two Corporations. American Journal of Healt Promotion 10(20): 148-53.

Dejoy MD (1996). Theoretical Models of Health Behavior and Workplace SelfProtective. USA: Journal of Safety Research, 27(2): 61-72. 
Depkes RI (2010). Data sasaran 2014. http://www.depkes.go.id. Diakses 1 April 2016.

Fikawati S, Syafiq A (2009). Penyebab Keberhasilan dan Kegagalan Praktik Pemberian ASI Eksklusif di Puskesmas Jagakarsa Jakarta. Jurnal Kesehatan Masyarakat UI, 4 (3).

Giri IA, Dian A (2013). Determinan Perilaku Pemberian ASI Eksklusif Pada Ibu Bekerja.UI; Jurnal Kesmas Nasional, 7 (7).

Glanz K, Barbara KR, Viswanath K (2008). Health Behavior and Health Education, Theory, Research, and Practice. San Fransisco; Jossey-Bras.

Green LW, Ottoson JM (2006). A Framework for Planning and evaluation; PRECEDE-PROCEED, Evaluation and Application of The Model. Montreal, Jurnees de sante publique.

Guendelman S, Kosa JL, Pearl M, Graham S, Goodman, Kharazzi M (2009). Juggling Work and Breastfeeding: Effects of Maternity Leave and Occupational Characteristics. American Academy of Pediatric 10. 98-4275.

Hilala A (2013). Faktor-faktor yang berhubungan dengan pemberian ASI eksklusif diwilayah kerja puskesmas Tuladenggi, kecamatan Telaga Baru. E-journal Universitas Negeri Gorontalo tahun 2014.

IDAI (2010). Indonesia Menyusui. Badan Penerbit IDAI.

ILO (2015). Indonesia; Tren Sosial dan Ketenaga Kerjaan Agustus 2014. ILO Jakarta, WWW.ILO.Org diakses 17 Maret 2016.

Indriyani A (2009). Pengaruh Konflik Peran Ganda dan Stress Kerja terhadap Kinerja Perawat Wanita Rumah Sakit (Studi pada Rumah Sakit Roemani Muhamadiyah Semarang). E-Journal UNDIP.
Kemenkes RI (2014). Health Statistics, Profil Kesehatan Indonesia Tahun 2013. Jakarta: Kemenkes RI.

Khasanah N (2010). ASI atau Susu Formula Ya?. Yogyakarta : FlashBooks.

Kusumaputri DP, Lestari S (2015). Pembagian Peran Dalam Rumah Tangga Pada Pasangan Suami Istri Jawa. Jurnal Penelitian Humaniora, UMS 16 (1): 72-85.

Kramer MS, Chalmers B, Hodnett ED, Sevkovskaya Z, Dzikovich I, Shapiro S, Paulcollet J (2001). Promotion of Breastfeeding Intervention Trial (PROBIT): A Randomized TrialIn The Republic of Belarus. Journal of the American Medical Association, 285(4): 413-420.

Kurniawan B (2013). Determinan Keberhasilan Pemberian Air Susu Ibu Eksklusif. Jurnal Kedokteran Brawijaya, Vol. 27 (4).

Lestari A (2012). Motivasi Ibu Bekerja Dalam Memberikan ASI Eksklusif di PT Dewri Men's Wear Indonesia. Jurnal Unpad. 1 (1).

Lusiana N, Andriyani R, Megasari M (2015). Buku ajar metodologi penelitian kebidanan. Yogyakarta: Depublish.

Mansyur F (1996). Analisis Gender dan Transformasi Sosial. Yogyakarta; Pustaka Belajar.

Mensesneg RI (2003). Undang Undang RI No 13 Tahun 2003 Tentang Ketenaga Kerjaan.

Moleong JL (2010). Metodologi Penelitian Kualitatif. Bandung: Rosdakarya.

Murti B (2013). Desain Dan Ukuran sampel Untuk Penelitian Kuantitaif dan Kuali tatif Di Bidang Kesehatan. Yogjakarta; UGM Press.

Ogbuanu C, Glover S, Probst J, Liu J, Hussey J (2010). The Effect Of Maternity Leave Length and Time of Return to Work on Breastfeeding. American 
Academy of Pediatrics: 10. 1542/peds. 2010-0459.

Peraturan Bersama Meneg PP, Menakertrans dan Menkes 0.48/Men.PP/XII/ 2008,PER.27/MEN/XII/2008,177/M enkes/PB/XII/2008 tentang Peningkatan Pemberian ASI Selama Waktu Kerja di Tempat Kerja. Jakarta: Dit. Bina Kesga dan Olahraga Kemenkes, 2010.

Peraturan Pemerintah RI No 24 tahun 1976. Tentang Cuti Pegawai Negeri Sipil RI.

- No 33 tahun 2012. Tentang Pemberian Air Susu Ibu Eksklusif.

Permenkes RI No 15 Tahun 2013. Tentang Tata Cara Penyediaan Fasilitas Khusus Menyusui dan Atau Memerah Air Susu Ibu.

Kemenkes RI (2015). Mari Dukung Menyusui dan Bekerja.

(2014). Situasi dan Analisis ASI Eksklusif.

Ratnaningsih D (2015). Faktor-Faktor yang Mempengaruhi Perilaku Pencegahan HIV/AIDS Pada Wanita Pekerja Seks Komersial (Tesis). Surakarta: Pascasarjana Ilmu Kesehatan Masyarakat UNS.

Rea MF, Venancio SI, Batista LE, Greiner T (2010). Determinants Of The Breastfeeding Pattern Among Working Mothers in Sao Paulo. J Hum Lacta 15(3).

Riskianti A, Prasodjo R, Novianti N (2014). Analisis faktor keberhasilan Praktik Pemberian ASI Eksklusif di Tempat Kerja Buruh Industri Textile di Jakarta. Buletin Penelitian Kesehatan Depkes, 42 (4).

Roesli U (2013). Mengenal ASI Eksklusif. Indonesia: Trubus Agriwidya.
Scott JA, Binns CW, Oddy WH, Graham KI (2005). Predictors of Breastfeeding Duration: Evidence From a Cohort Study. American Academy of Pediatrics. 10.1542/peds 2005-1991.

Slame R (2012). Paradigma Perempuan Perlindungan Terhadap Perempuan Pekerja Di Dunia Kerja dan Kesehatan Reproduksi Dalam Perspektif Islam, Kebijakan Negara dan Realitas. www. Gizikia.depkes.go.id diakses tanggal 11 mei 2015.

Smith LJ (2009). Long-Term Pumping When Direct Breastfeeding Doesn't Work Out. http://www.bflrc.com/ljs/breastfeeding/bfnotwk.htm.

Diakses 4 april 2016.

Sujiyatini (2010). Asuhan Ibu Nifas. Cyrillus Publisher. Yogyakarta : KTD.

Sulaiman ES (2015). Metode Penelitian Kualitatif dan Campuran. Surakarta: UNS Press.

Suratiyah K, Molo M, Abdullah I (1999). Dilema Wanita Antara Industri $\mathrm{Ru}-$ mah Tangga dan Aktivitas Domestik. Yogyakarta: Aditya Media.

Victora CG, Bahl R, Barros AJ (2016). Breastfeeding In The 21st Century: Epidemiology, Mechanisms, and Lifelong Effect. Lanset Breastfeeding series group: 30;387(10017):475-90.

WHO (2011). The goal Breasfeeding. www.who.int/nutrition. diakses 1 april 2016.

Wulandari SR, Handayani S (2011). Asuhan Kebidanan Ibu Masa Nifas. Yogyakarta: KDT. 